\title{
FEDERAL PAYMENTS TO STATES AND LOCAL GOVERNMENTS RESPECTING PROPERTY OF THE UNITED STATES
}

\section{Joseph Guandolo $†$}

In this era of pyramiding costs of government, high taxes, and pressing demands for more public facilities and increased public services, states and local governments are more acutely aware of the burdens imposed upon their economy by federal property. War and defense needs, conservation measures and other general welfare activities have in recent years engendered federal programs, unparalleled in our history, involving the acquisition of vast tracts of land and the provision of huge military reservations, gigantic industrial installations, extensive housing facilities and innumerable other improvements. The types of property in federal ownership range from desert and mountainous wastelands to highly improved, extremely valuable urban and industrial properties. ${ }^{1}$ Of the total land area in the 48 states and the District of Columbia almost one-fourth is owned by the United States. Tax immunity $^{2}$ and the use and occupancy of federal property have contributed immeasurably to the stringency of the local governmental economy.

Numerous federal statutes have been enacted-one even as early as March 3,1803-providing for payments to states and local governments with respect to federally-owned property. ${ }^{3}$ These statutes have authorized tax payments, payments in lieu of taxes, a sharing of revenues and of proceeds derived from federal property, and other types

†A.B., McKendree College; J.D., University of Illinois; J.S.D., Yale University. Associate General Counsel, Housing and Home Finance Agency. The opinions expressed herein are those of the author and do not necessarily express the views of HHFA or any other Federal agency.

1. H.R. Doc. No. 216, 78th Cong., 1st Sess. 4 (1943) ; H.R. REP. No. 3116, 81st Cong., 2d Sess. (1950); SEN. Doc. No. 130, 78th Cong., 1st Sess. (1943); H.R. Doc. Serial No. 22, Nov. 15, 1949, Committee on Public Lands Print, issued pursuant to H. Res. 66, 81st Cong., 1st Sess.; SENzEI, INCREAse IN FEDERAL LAND OWNERSHIP, 1937-1945 (1949).

2. Maricopa County v. Valley National Bank of Phoenix, 318 U.S. 357 (1943); Federal Land Bank of St. Paul v. Bismark Lumber Co., 314 U.S. 95 (1941); Pittman v. Home Owners Loan Corp., 308 U.S. 21 (1939); Van Brocklin v. Tennessee, 117 U.S. 151 (1886); McCulloch v. Maryland, 4 Wheat. 316 (U.S. 1819); cases collected in 51 AM. JUR. $\$ \$ 211-250$ (1944); 1 Cooley, A Treatise on the Constitutional Limitations 989-995 (1927); 1 'Wllloughby, THE CoNSTITUTtonal LAW OF THE UNITEd States 144-165 (1929).

3. Statutes collected in Notz, ACTS of Congress Providing for Grants-INAm to States 20-28 (Libr. Cong. Legis. Ref. Ser. 1947); Sen. Doc. No. 101, 82d Cong., 2d Sess. 312 (1952) ; H.R. Doc. No. 216, 78th Cong., Ist Sess. 39-41 (1943) ; Exec. Communication No. 722, Regarding Payments in Lieu of Taxes, Director, Bureau of Budget to Speaker of the House 18 (Aug. 16, 1951); STAtus and Fiscal Significance of Federal Lands in Eleven Western States 13 (Nat1. Ed. Ass'n 1950). 
of contributions. ${ }^{4}$ Striking diversities of treatment and of result are typical. The statutes and their administration reflect no consistency of policy, establish no over-all standards, assure no regularity of payment and provide no uniformity of treatment. Moreover, most federal agencies have no authority to make any payments in connection with property under their jurisdiction.

In consequence, numerous appeals for more equitable treatment have been directed to the executive departments and the Congress. ${ }^{5}$ Scores of bills have been introduced, manifesting a wide diversity of views as to the proper solution of the problem. Several of the bills have provided either for payment of full taxes or for payment of the equivalent of full taxes on practically all federal property, improved and unimproved. ${ }^{b}$ The executive branch for a number of years has had under review federal policies in relation to the tax-exempt status of federal property. Pursuant to Executive Order 8034, promulgated on January 14, 1939, the Federal Real Estate Board made a study of this problem lasting several years. On May 26, 1943, the President submitted to the Congress the Board's report and recommendations. ${ }^{7}$ No action was taken by the Congress. In April, 1949, the problem was discussed at length in a conference on intergovernmental tax problems and fiscal relations attended by federal, state and local government officials and representatives. ${ }^{8}$

In accordance with the general understanding reached at the 1949 intergovernmental conference, the Bureau of the Budget prepared and on August 16, 1951, submitted to the Congress a draft of a Bill for a comprehensive program of payments in connection with federallyowned property. The Bill, which was introduced as H. R. 5223 and S. $2268,{ }^{9}$ died in committee with the $82 \mathrm{~d}$ Congress.

4. Such payments must be distinguished from federal grants-in-aid and contributions made to states and local governments for purposes having little or no relationship to the alleviation of fiscal burdens imposed by the ownership, use and occupancy of federal property. For tabulations of federal payments see SEN. Doc. No. 101, 82d Cong., $2 \mathrm{~d}$ Sess. $1-4,11-16,318-319$ (1952); see also H.R. Doc., A List of Payments to the States and Other Local Governments by the Departments of the Federal Government by Reason of the Sale of U.S. Government Lands or Other Operations Thereon (House Committee on Public Lands, 1945); 10 FEDERAL Works Agency A.n. Rep. 112-116 (1949).

5. Canada recently enacted legislation for federal payments to local governments respecting tax-immune federally-owned property. The Municipal Grants Act, 14 \& 15 GEo. 6, c. 54 (1951) ; 92 H.C. DEB. 4216-4227 (1951).

6. See H.R. 1356, 81st Cong., 1st Sess. (1949); H.R. 2417, 82d Cong., 1st Sess. (1951) (introduced by Senator Nixon); S. 2308, 77th Cong., 2d Sess. (1942); see also 31 GEo. L.J. 315 (1949) ; 18 TENN. L. REv. 562 (1945).

7. H.R. Doc. No. 216, 78th Cong., 1st Sess. (1943). The Federal Real Estate Board has been abolished under ExEc. ORDER No. 10287, 16 FED. REG. 9137 (1951).

8. U.S. Treas. Dep't. News Release, April 22, 1949.

9. 82 Cong. Rec. 13,320-13,325 (1951). In Exec. Communication No. 722, supra note 3 , accompanying the Bill, reference is made to the problem of the exemption of interest on state and municipal bonds from federal income taxes. Such an issue should not be confused with the problem of payments respecting federal prop- 
Since the Bill constitutes the first definitive proposal of the executive branch for comprehensive legislation respecting payments to states and local governments in connection with federal property, there is sufficient interest in the proposed legislation to indicate that it may be reintroduced in the Congress.

General Nature of Proposed Legislation. The general objective of the Bill is to avoid inequities between state and local taxpayers in the distribution of tax burdens and governmental costs associated with the ownership or use of property by the Federal Government. In furtherance of such objective, the Bill, with respect to various classes of property, authorizes tax-equivalent payments, provides for transition payments for a limited period, grants consent to the levy of taxes and special assessment, makes provision for supplementary payments in hardship cases, continues in force certain statutory provisions authorizing payments, and repeals most of the existing statutory provisions consenting to the levy of taxes, the making of payments in lieu of taxes or other payments, or prescribing tax-immunity.

Cut-off Date. H.R. 5223 and S. 2268 are companion Bills but vary as to title and other minor provisions. They also differ in one major respect. H.R. 5223 fixes January 1, 1946, as the cut-off date, excluding from the purview of the bill any property acquired or constructed by the Federal Government prior to such date, with certain exceptions. S. 2268, however, omits the cut-off date but contains blank spaces for the future insertion of a cut-off date. The cut-off date in S. 2268 was omitted, it has been explained, ${ }^{10}$ because the federal impact began in 1939 and 1940 and, therefore, the cut-off date should be earlier than 1946.

The Bureau of the Budget justifies the inclusion of a cut-off date upon grounds of equity and suggests that the choice of an appropriate cut-off date is largely a matter of comparing the cost to the Federal Government with the current burdens which federal property ownership may create for local taxpayers. ${ }^{11}$

Three different cut-off dates have been considered for inclusion in the Bill: July 1, 1950, representing the approximate commencement of the Korean conflict; January 1, 1946, representing the approximate termination of World War II; and September 8, 1939, the date of the President's proclamation of the existence of a national emergency. The

erty. The latter problem is sufficiently complicated without injecting the issue, equally complicated and far more controversial, of federal taxation of interest on state and municipal securities.

10. 82d CoNG. REC. 13,320 (1951).

11. Exec. Communication No. 722 , supra note 3 , at 2 and 8 . See also Report of Housing and Home Finance Administrator of Dec. 5, 1951, on S. 2268 to Senate Committee on Expenditures in Executive Departments. 
importance of choosing an appropriate cut-off date is obvious. The earlier cut-off date will increase substantially the amount of federal payments under the Bill, particularly with respect to Department of Defense property. ${ }^{12}$

Tax-Equivalent Payments Under the Bill. Section 101 of the Bill authorizes payments to states and local governments on account of federal property used or held for activities which serve primarily national or broad regional interests, subject to certain prescribed exceptions. Such payments are to be reasonable in amount and determined by each owning agency in conformity with rules and regulations prescribed by a commission established under the Bill. The commission in connection therewith must give consideration to certain factors listed in section 101(b) (1) to (7). Payments will be based generally on an estimate of taxes with adjustments for special services rendered by the Federal Government. The estimate of taxes will be predicated with respect to most of such properties upon the value of the property, exclusive of improvements made or personal property added by the Federal Government after its acquisition of the property. However, with respect to commercial and industrial properties the value of both improvements and certain tangible personal property will be added.

Payments on Housing Properties. Section 102 of the Bill authorizes payments in lieu of taxes to states and local governments on real properties owned by the Federal Government for housing purposes, including housing under (a) the rural resettlement or rehabilitation program and (b) the various defense housing acts. The payments are to approximate the taxes that would be paid upon the real property if it were not tax-exempt, less an allowance for federal services.

Transition Payments. Transition payments are authorized under section 104 for certain properties which are otherwise exempt from payments under the Bill. The transition payments are to be made for a temporary period to afford local governments a reasonable opportunity to adjust their finances by reason of the removal of the property from the tax rolls or the termination of payments in lieu of taxes.

Consent to Levy Taxes under Bill. Title II of the Bill grants consent to the levy of state and local property taxes upon three classes of federal properties: (a) properties acquired by the Federal Government in connection with loans or contracts of insurance or guaranty, while held pending disposition; (b) properties leased or sold under conditional sales contracts to private persons; and (c) properties presently subject to taxation if the agency having jurisdiction determines

12. Exec. Communication No. 722, supra note 3, at 19-20. 
the policy of the Act will be better served by continuing the tax status. Under Title II tangible personal property with a fixed situs is included in the category of taxable property.

Consent to Special Assessments. Title III of the Bill grants consent to any state or local government to levy special assessments for local improvements against federal real property in the same manner as against real property privately owned.

Supplementary Payments for Hardship Cases. Title IV is intended as a legislative cushion to afford relief in hardship cases. It adds some degree of flexibility in meeting special situations in the light of actual experience by authorizing supplementary payments under certain conditions.

Existing Statutes. Consistent with the general purpose of providing a comprehensive system of payments, the Bill repeals ${ }^{13}$ most of the existing federal statutes which (a) provide for payments with respect to federal property, (b) consent to the levy of taxes thereon, or (c) prescribe tax immunity therefor. Section 508(a) (2) excepts certain statutory provisions from this general repealing provision and under section 3 (d) low-rent public housing and public domain lands, with minor exceptions, are excluded from the purview of the Bill. The statutory provisions involved are continued in force under the Bill because the payments thereunder are deemed adequate.

Property Exempt from Payment. Under section 103 certain types of federal properties are exempt from federal payments under the Bill (except for transition payments), including: (a) properties used or held primarily for purposes for which properties under private ownership would be exempt from taxation under pertinent state laws; (b) properties used or held primarily for services to the local public, such as courthouses and post offices; (c) land conservation properties; (d) office buildings (with certain exceptions), penal or welfare institutions, navigation aids, etc.; and (e) tangible personal property used primarily in connection with real property not subject to payments under Title $I$ of the Bill.

Authority Vested in Agencies. The Bill vests responsibility for administering the payments authorized thereunder in the particular federal agencies having jurisdiction over the property involved.

Creation of a Commission and Advisory Committee. In order to foster uniform interpretations and applications of Government-wide policies under the Bill, Title $\mathrm{V}$ provides for a three-member commission

13. For a list of the agencies and of the citations involved, see Executive Communication No. 722 , supra note 3 , at 18 . 
composed of the Director of the Bureau of the Budget, the Secretary of the Treasury, and the General Services Administrator. Provision is also made for the appointment of an advisory committee to the commission consisting of representatives of federal agencies and of national associations of state and local government officials.

Miscellaneous Provisions of Bill. Many other provisions, some procedural in nature, others designed to protect the federal interest, have been incorporated into this legislation. All functions performed under the Bill are exempt from the operation of the Administrative Procedure Act, ${ }^{14}$ except as to the public information requirements of section 3. In determining the amount of payments the controlling elements will be the amount of taxes collected, revenue losses, assessed valuations, additional local expenditures for services, federal services provided and other relevant facts. An anti-bounty provision to prevent payment of unreasonably large amounts to particular local governments is included.

Objections to Bill. A report submitted by one of its committees to a national organization of municipal officers criticizes the complexity of the Bill and certain other features. ${ }^{15}$ The Bill is lengthy, covering 42 printed pages, and lacks simplicity. However, the nature of the subject matter and the objectives sought to be attained contributed immeasurably to the length and complexity of the proposed legislation.

Among the objections cited in the report, those respecting the lack of judicial review, the finality of decisions of federal agencies, and the exemption of functions under the Bill from the Administrative Procedure Act, overlook the underlying legal principle upon which the Bill is predicated. The Bill is based upon the principle, enunciated in section 2, that "the Federal Government is under no constitutional obligation to pay taxes or to contribute to the states or local governments any sums in lieu of taxes on account of property owned by the Federal Government." The consent to tax and the payments authorized under the Bill, however justified upon grounds of equity and public policy, are in legal effect matters of grace with the Federal Government and not obligatory. Payments of taxes or in lieu of taxes constitute grants or contributions. Under the Administrative Procedure Act the rule-making provisions generally are not applicable to matters relating to public property, loans, grants, benefits or contracts. The public information requirements of the Administrative Procedure Act will be applicable to the functions performed under the Bill. Moreover,

14. 60 STAT. 237-244, 5 U.S.C. $\$ \$ 1001-1011$ (1946).

15. MUNictpalimies AND THE LAW IN ACtion 92-96 (National Institute of Municipal Law Officers, 1952). 
the coordinating commission and the advisory committee, authorized by the Bill, may exercise surveillance functions, protective of the interests of the parties concerned. Neither judicial review nor review by the Tax Court of the United States, as provided in certain bills on this subject introduced in the $82 \mathrm{~d}$ Congress, appear necessary or desirable.

Merits of Bill. The Bill obviously represents an attempted compromise of the views of those who advocate the taxation of practically all federal property on the one hand and those, on the other, whose sympathies are in favor of continuing the tax-exemption of federal property with little modification in present laws. Whatever its weaknesses and inadequacies, the Bill definitely manifests substantial progress towards the solution of this perplexing problem.

The objective of having comprehensive, over-all federal legislation prescribing uniform standards and guides and giving statutory recognition to the Federal Government's responsibilities to states and local governments in connection with federal properties is eminently sound and desirable. The principle of tax immunity for federal properties was established in a period when federal functions and activities were narrowly circumscribed and impinged lightly upon municipal life. The broad extension of federal functions and federal property ownership, and their weighty impact upon local governments, have led to a realistic recognition in S. 2268 that the Federal Government to all practical purposes must shed its tax-immunity cloak on a comprehensive basis. Basically the problem is merely one of equity and fair play. S. 2268 attempts to provide a solution which is at once fair and equitable both to the Federal Government and the states and local governments and justly balances the interests of federal taxpayers against those of state and local taxpayers. For the first time prompt and decisive action is possible. Disputes over details and efforts to attain ideal legislation may deter Congressional action and again mire the proposed legislation in prolonged discussions and continued studies. ${ }^{16}$

16. State Constitutional and statutory provisions exempting federal property from taxation perhaps should be repealed in order to take full advantage of any federal legislative enactments waiving tax immunity or authorizing payments in lieu of taxes on federal property. Several states in recent years have amended their constitutions to remove blanket exemptions of federal properties, e.g., WASH. CoNST. AMEND. XIX. See Boeing Aircraft Co. v. R.F.C., 25 Wash.2d 652, 171 P.2d 838, cert. denied, 330 U.S. 803 (1946); 168 A.L.R. 547 (1947); STATUS AND FISCAL SIGNIFICANCE OF FEDERAI LANDS IN ELEVEN WESTERN ŚTATES 9 (Nati. Ed. Ass'n 1950). Another fruitful undertaking for states and local governments may be the extension of $\operatorname{tax}$ laws where necessary to encompass, to the extent permissible under federal law, privately-held property interests in federal lands, such as those of lessees of federal properties, private contractors operating on federal lands, and people employed or residing on federal properties. See 4 U.S.C. $\$ \$ 104-109$ (1946); Carson v. Roane-Anderson, 342 U.S. 232 (1952); United States v. County of Allegheny, 322 U.S. 174 (1944); Alabama v. King \& Boozer, 314 U.S. 1 (1941); James v. Dravo Contracting Co., 302 U.S. 134 (1937); Conference of Governors' Resolution, 25 State Governarent 188 (1952); S. 3040, 82d Cong., 2d Sess. (1952). 